\title{
The Teaching Quality of Teachers in a Learning Process
}

\author{
Susanti \\ SD Negeri 24 Banyuasin \\ Email: wahyudisanti039@gmail.com \\ Edi Harapan \\ Universitas PGRI Palembang, Indonesia \\ e-mail: ehara205@gmail.com \\ Nila Kesumawati \\ Universitas PGRI Palembang, Indonesia \\ e-mail: nilakesumawati@yahoo.com \\ Article History: Received on 21 November 2021, Revised on 30 January 2022 \\ Published on 2 February 2022
}

\begin{abstract}
This study attempts to describe the teaching quality of teachers in learning in SD Negeri 24 Banyuasin. The qualitative was used in this study. Informants in research were head of school and teachers. The data collection in this study using interviews. The results suggests that the quality of teachers faced lack of facility system, lack of funds, then it needs strategy to maximize resources which will run the learning well and the achievement of students gained.
\end{abstract}

Keywords: Quality, Teacher, Learning Process

\section{A. Introduction}

Teachers in the learning process has a very important role. The teacher could not be replaced by other devices like television, radio, and computer. Because students is an organism that requires developing guidance and help from adults. Teacher is one of the most important elements in education. Good and poor quality of education is very determined by the standard quality of teachers (Nuryani et al, 2021). Hence, the competence of teachers need to increase as in Law 14 year 2005.

There are four teacher's competence must be fulfilled, the pedagogy, personality, professional, social competence. The competence of teachers in indonesia must be improved. Education and culture ministry realized this and anticipate it by making standard in indonesia mapping competence of teachers. Training teachers have done to increase the competency, including training teaching adapted to the utilization of technology (Yusutria, 2016; Warsono, 2016; Sudrajat, 2018).

New challenges that emerged is a challenge of normative certification as professional teacher. It is new hope relating to the welfare of teachers, and certain standard of professional teacher. By the standards of the quality, it assures somebody could be described as a professional teacher. The certificate as professional teachers must pass the teacher competency test. There are two main criteria a requirement to get to this intention 1) qualified academic minimum four formal education Diploma (D-IV) or (Undergraduate); and 2) standard competence as agents of learning. 
Educator must have academic qualifications and competencies as agents of learning, spiritual and physical health, as well as the ability to realize national education targets. Academic qualification is the education level intended and evidenced by transcripts and certificates relevant expertise. Become teachers not like a politician who could build a promise or a comedian who prosecuted can make audience laugh and amused. Become a teacher can be a as darkness in thought and satisfying hunger and curiosity students. The job of a teacher not just implement learning with theory and wisdom but should implement stimulus learning activities and students' skill according to their capacity. The main task of teacher is to educate which means not only share knowledge to students but educate students in terms of attitudes and act (Rizaldi, 2014).

Teaching quality is one of the important to improve the quality of education. This capability obtained from long process. By the process, we can obtain competence figures in their field (Usman, 2012). Efforts to improve the quality of teachers had been undertaken by the government in various ways including by granting school block to run the program for a stimulant of teacher professional development, establishing an association subject teachers, forming the scientific forums teachers and publishing scientific journal for teachers and teachers working group program present in almost each district/city (Gusmiyati et al, 2021).

Programs development especially the quality of teachers aims to upgrading the skill in planning, implementing learning (Sumardin, 2016). Management class is the education which are often used as the main concern by the new teacher, even a teacher who have experienced hopes can learn optimal (Muningsih, 2015; Nurkhotijah, 2016). This study focused on the quality of teachers to teach in learning in terms of: (1) teachers in planning learning, (2) teachers in implementing learning, (3) teachers in doing the evaluation of lessons, (4) teachers in addressing lessons, and (5) teachers in providing guidance and counseling. This study also examines the obstacles that teachers face in the learning process (Angraini et al, 2021).

\section{B. Methods}

This study using a qualitative and done in field. This study specially is designed to describe the phenomenon faced in social relating to the quality of teachers in the process of learning in SD Negeri 24 Banyuasin. The informants of interviewee in this study are teachers of SD Negeri 24 Banyuasin. The data were collected using interviews, observation and documentation then analyzed using triangulation (Sugiyono, 2015).

\section{Results and Discussion}

Based on the research done, it is revealed as follows: (1) teachers have to regulate students in learning; (2) obstacles of teachers were the low grade, where the students still hard to get good result; (3) usually teachers are doing a strategy to regulate students in a learning process for low grade to sing and answer questions from teachers; (4) teachers set materials at the time of learning, students clean classrooms if there are still dirty, and tidy facilities in the classroom; (5) overcome obstacles; (6) the strategy took by teachers in regulating facilities was sending students to clean classrooms; (7) teachers generally in creating and maintaining the learning are good and students active in learning delivered by teachers (Feri, 2017; Gangsar, 2012; Marulloh, 2015); (8) generally obstacles that teachers face in creating and maintaining the learning is one parents near. Because learning by parents did not go into the room. This research 
Volume 3 (1) 2022

E-ISSN: 2723-6919 P-ISSN: 2746-0827

is in line with a number of studies Mardalena, et al, (2020), where the results explained there are significant influence on the performance of teachers academic supervision, in SMK Tanjung Raja. There are significant influence on the performance of teachers professional competency. There are significant influence of academic and professional competency together on the performance of teachers. This study looks at competence of teachers pertaining to teaching methods teacher eventually contributing to quality (Hidayat, 2012).

\section{Conclusion}

Based on the research and discussion, it can be taken the conclusion that the quality of teachers to teach in the learning process in SD Negeri 24 Banyuasin capable of management implementation of the learning process. The obstacles that teachers face in the implementation of the learning was lack of funds and other supporting infrastructure.

\section{E. Acknowledgement}

Thank to SD Negeri 24 Banyuasin, Rector Universitas PGRI Palembang, Director of Graduate Program and friends of in educational management Universitas PGRI Palembang who have supported us to do this project.

\section{References}

Angraini, S., Fitria, H., \& Setiawan, A. A. (2021). The Effect of Teacher Performance and Learning Media on Learning Outcomes of Elementary School Students. Journal of Social Work and Science Education, 2(2), 137-146. https://doi.org/10.52690/jswse.v2i2.237

Feri, N. (2017). Manajemen Pembelajaran Guru Pada SD Negeri 1 Pelukan Pidie Kabupaten Pidie [Teacher Learning Management at SD Negeri 1 Pelukan Pidie, Pidie Regency]. Jurnal: Manajer Pendidikan, 9(5), 699-703.

Gangsar, F. U. (2012). Kemampuan Guru Mengelola Kelas 4 dan 5 SD Negeri Pandeyan Umbulharjo Yogyakarta [Teacher Ability to Manage Grades 4 and 5 SD Negeri Pandeyan Umbulharjo Yogyakarta]. Jurnal Manajemen Pendidikan, 2(2), 182-197.

Gusmiyati, G., Lian, B., \& Fitria, H. (2021). Principal's Supervision in Improving Teacher's Performance. Journal of Social Work and Science Education, 2(1), 83-94. https://doi.org/10.52690/jswse.v2i1.209

Hidayat, M. T. (2012). Kemampuan Guru dalam Mengelola Kelas dan Pengaruhnya Terhadap Prestasi Belajar Siswa Pada Mata Pelajaran IPS di MTs NU Astanajapura Kabupaten Cirebon [Teacher's Ability in Managing Classrooms and Its Influence on Student Achievement in Social Studies Subjects at MTs NU Astanajapura Cirebon Regency]. Jurnal Manajemen Pendidikan, 3(2), 216-231.

Law 14 year 2005

Mardalena, M., Arafat, Y., \& Fitria, H. (2020). Pengaruh Supervisi Akademik dan Kompetensi Profesional Guru terhadap Kinerja Guru di Sekolah Menengah Atas Negeri di Kecamatan 
Tanjung Raja [The Effect of Academic Supervision and Teacher Professional Competence on Teacher Performance in Public High Schools in Tanjung Raja District]. Jurnal Intelektualita: Keislaman, Sosial Dan Sains, 9(1), 103-114. https://doi.org/https://doi.org/10.19109/intelektualita.v9i1.5582

Marulloh. (2015). Peningkatan Kemampuan Guru dalam Mengelola Kelas Melalui Supervisi Klinis di SMAN 10 Bengkulu [Improving Teacher Ability in Managing Classes Through Clinical Supervision at SMAN 10 Bengkulu]. Jurnal Manajemen Pendidikan, 3(1), 282197.

Muningsih. (2015). Manajemen Kelas Guru Sekolah Dasar (Studi Analisis Pembelajaran Pada Siswa SDN 02 Curup Timur) [Class Management of Elementary School Teachers (Learning Analysis Study on Students of SDN 02 Curup Timur)]. Jurnal. Manajer Pendidikan, 9(5), 699-703.

Nurkhotijah, F. (2016). Keterampilan Guru dalam Pengelolaan Kelas Pada Pembelajaran Tematik Kelas V Ali Bin Abi Thalib di MIN Purwokerto [Teacher Skills in Classroom Management in Ali Bin Abi Talib's Fifth Grade Thematic Learning at MIN Purwokerto]. Jurnal Manajemen Pendidikan, 2(2), 112-127.

Nuryani, N., Harapan, E., \& Wardiah, D. (2021). Principal's Managerial in Improving the Quality of Education in Primary School. Journal of Social Work and Science Education, 2(1), 52-59. https://doi.org/10.52690/jswse.v2i1.205

Rizaldi, A. (2014). Dari Guru Konvensional Menuju Guru Profesional [From Conventional Teacher To Professional Teacher]. Jakarta: Grasindo.

Sudrajat. (2018). Manajemen Kinerja Guru Sekolah Dasar [Elementary School Teacher Performance Management]. Jurnal Administrasi Pendidikan, XXV(1), 104-119.

Sugiyono. (2015). Metode Penelitian Pendidikan, Pendekatan Kuantitatif, Kualitatif dan $R$ \& $D$ [Educational Research Methods, Quantitative, Qualitative and R\&D Approaches]. Bandung: Alfabeta.

Sumardin. (2016). Pengembangan Profesionalisme Guru Berbasis MGMP Model dan Implementasinya [Teacher Professionalism Development Based on MGMP Model and Its Implementation]. Yogyakarta: Budi Utama.

Usman, M. U. (2012). Menjadi Guru Profesional [Become a Professional Teacher]. Bandung: Remaja Rosdakarya.

Warsono. (2016). Pengelolaan Kelas dalam Meningkatkan Belajar Siswa [Classroom Management in Improving Student Learning]. Jurnal Manajemen Pendidikan, 3(1), 118132.

Yusutria. (2016). Profesionalisme Guru dalam Meningkatkan Sumber Daya Manusia [Teacher Professionalism in Improving Human Resources]. Jurnal Manajemen Pendidikan Volume 2 Nomor 3, Juli 2016. Halaman. 105-112. 